\title{
Differences in Religiousness in Opposite-Sex and Same-Sex Twins in a Secular Society
}

\author{
Linda J. Ahrenfeldt, ${ }^{1}$ Rune Lindahl-Jacobsen, ${ }^{1,2}$ Sören Möller, ${ }^{1}$ Kaare Christensen, ${ }^{1,3}$ Dorte Hvidtjørn, ${ }^{4}$ \\ and Niels Christian Hvidt ${ }^{5}$ \\ ${ }^{1}$ The Danish Twin Registry, Department of Public Health, University of Southern Denmark, Odense, Denmark \\ ${ }^{2}$ Max-Planck Odense Center on the Biodemography of Aging, University of Southern Denmark, Odense, Denmark \\ ${ }^{3}$ Department of Clinical Biochemistry and Pharmacology and Department of Clinical Genetics, Odense University Hospital, \\ Odense, Denmark \\ ${ }^{4}$ Institute of Clinical Research, University of Southern Denmark, Odense, Denmark \\ ${ }^{5}$ Research Unit of General Practice, Department of Public Health, University of Southern Denmark, Odense, Denmark
}

Sex differences in religion are well known, with females generally being more religious than males, and shared environmental factors have been suggested to have a large influence on religiousness. Twins from opposite-sex (OS) and same-sex (SS) pairs may differ because of a dissimilar psycho-social rearing environment and/or because of different exposures to hormones in utero. We hypothesized that OS females may display more masculine patterns of religiousness and, vice versa, that OS males may display more feminine patterns. We used a web-based survey conducted in Denmark, which is a secular society. The survey included 2,997 twins aged 20-40 years, identified through the population-based Danish Twin Registry. We applied la Cour and Hvidt's adaptation of Fishman's three conceptual dimensions of meaning: Cognition, Practice, and Importance, and we used Pargament's measure of religious coping (RCOPE) for the assessment of positive and negative religious coping patterns. Differences between OS and SS twins were investigated using logistic regression for each sex. The analyses were adjusted for dependence within twin pairs. No significant differences in religiousness and religious coping were found for OS and SS twins except that more OS than SS females were members of the Danish National Evangelical Lutheran Church and fewer OS than SS females were Catholic, Muslim, or belonged to other religious denominations. Moreover, OS males at age 12 had higher rates of church attendance than did SS males. This study did not provide evidence for masculinization of female twins with male co-twins with regard to religiousness. Nor did it show any significant differences between OS and SS males except from higher rates of church attendance in childhood among males with female co-twins.

Keywords: religion, religious coping, opposite-sex, same-sex, twins

Females have been shown to be more religious than males (Deaton, 2009; Trzebiatowska \& Bruce, 2012). This pattern has also been found in Denmark, which is a secular society with low rates of church attendance and religion playing only a minor role in public life (Zuckerman, 2008). A recent Danish survey study based on the same study population as in this study demonstrated sex differences in religiousness (Hvidtjorn et al., 2014). The study found that approximately $60 \%$ of females believed in some sort of spirit or in God compared with $40 \%$ of males. Also, within OS twin pairs, females were more religious than males (Hvidtjorn et al., 2014).

For many people, religion remains a well-documented beneficial coping strategy (Pargament et al., 2000; Winter et al., 2009). Religious coping is described as the way individuals actually draw on religion in a situation with a crisis, and has been conceptualized as encompassing potentially positive and negative religious coping styles (Winter et al., 2009). Positive religious coping may imply finding meaning, control, comfort, and closeness to God; whereas negative religious coping patterns may feature punishing reappraisal (feeling punished by God for one's sins; Winter et al., 2009). Studies on coping strategies also suggest that

RECEIVED 18 June 2015; ACCEPTED 22 September 2015. First published online 22 December 2015.

ADDRESS FOR CORRESPONDENCE: Linda Juel Ahrenfeldt, The Danish Twin Registry, University of Southern Denmark, J. B. Winsløws Vej 9B, 5000 Odense, Denmark. E-mail:lahrenfeldt@health.sdu.dk 
females are more likely to use religious coping than males (Hvidtjorn et al., 2014; Pargament, 1997).

Religiousness is influenced by both genetic and environmental factors, but is generally considered to be a culturally transmitted trait with strong shared environmental influences (Koenig et al., 2009). The genetic effect is small in childhood (Koenig et al., 2008), but increases with age (Koenig et al., 2005; 2008). A Danish study investigating the genetic and environmental influence on religiousness found high correlations within both monozygotic (MZ) and dizygotic (DZ) twin pairs for most of the items of religiousness, indicating both genetic and shared environmental factors (Hvidtjorn et al., 2013). They found that twins in a pair were very alike regarding religiousness and that this similarity was due rather to shared environment than to genetic factors. Social forms of religiousness such as church attendance were mostly influenced by the shared environment, whereas more personal religiousness such as belief in God was influenced equally by shared environmental and genetic factors (Hvidtjorn et al., 2013).

Relatively little is known on inter-twin relationships and their consequences (Rutter \& Redshaw, 1991), but twinship has been presented as one of the most unique and intimate of interpersonal bonds (Neyer, 2002; Segal, 1999). OS twins may be different from SS twins because they are raised in a different gender-related social environment with different socialization experiences (Cohen-Bendahan et al., 2005; Henderson \& Berenbaum, 1997). A large study of 1,874 11- to 12-year-old twins and their 23,200 non-twin classmates found differences in peer-assessed socio-emotional behavior between OS and SS twins (Pulkkinen et al., 2003). They found that OS females were rated higher than samesex dizygotic (ssDZ) females in socially active behavior, and that OS males were rated higher than ssDZ males in adaptive behavior. In particular, social interaction, popularity, and leadership were evident among OS twins (Pulkkinen et al., 2003). The Finnish study also found that gender differences were smallest within OS twin pairs, in line with evidence from non-twin families, suggesting sex-typed effects from an older sibling (McHale et al., 2001; Rust et al., 2000). However, other twin studies - for instance, of activity interests (toy play) - failed to detect differences between OS and SS twins (Henderson \& Berenbaum, 1997; Rodgers et al., 1998). Furthermore, the few twin studies using siblings as a control group for the psychosocial environment have also failed to find evidence for socialization effects (Heil et al., 2011; Slutske et al., 2011).

Except for differences in the postnatal environment, OS and SS twins may also differ because of different exposure to sex hormones in utero (Miller, 1994). Studies in rodents and swine have demonstrated prenatal hormonal interaction between fetuses, resulting in females developing between males being masculinized in several anatomical, physiological, and behavioral traits (Ryan \& Vandenbergh, 2002; vom Saal, 1989). Likewise, female fetuses develop- ing between females show more feminized traits as adults (Ryan \& Vandenbergh, 2002). However, irrespective of sex, a fetus located between two male fetuses has higher blood concentrations of testosterone and lower concentrations of estradiol than fetuses located between two females (Ryan \& Vandenbergh, 2002; vom Saal, 1989). More than 50 years ago, the first animal study was published showing that prenatal exposure to testosterone masculinized the behavior of female guinea pigs (Phoenix et al., 1959). Later studies in, for instance, rhesus monkeys have demonstrated a masculinized play behavior of female monkeys who were treated prenatally with testosterone (Phoenix, 2009). Evidence that testosterone influences human neurobehavioral development comes from clinical populations of individuals exposed to atypical hormone exposure in utero (CohenBendahan et al., 2005). For example, females with congenital adrenal hyperplasia (CAH) who are exposed to high levels of androgens prenatally show increased male-typical and decreased female-typical behavior (Hines, 2011). Some studies in human twins suggest that variability in certain masculine and feminine traits may be due to intrauterine hormone exposure (Tapp et al., 2011). Small sample twin studies have, for instance, found OS females to be more masculine than SS females on traits such as sensation-seeking (Resnick et al., 1993; Slutske et al., 2011), rule-breaking (Loehlin \& Martin, 2000), and social attitudes (Miller \& Martin, 1995), but other studies did not find any differences (Laffey-Ardley \& Thorpe, 2006; Rose et al., 2002). There is some suggestion that OS male twins might be demasculinized or feminized on gender-role behavior (CohenBendahan et al., 2005; Elizabeth \& Green, 1984), although most studies have failed to identify differences between OS and SS males in the direction predicted by the twin testosterone transfer (TTT) hypothesis (Cohen-Bendahan et al., 2005; Tapp et al., 2011).

Here, we investigate, in a Danish twin cohort, potential influences of having a co-twin of the opposite sex versus having one of the same sex on religiousness and religious coping. We hypothesized that OS female twins would be masculinized in religiousness as they have grown up with a male co-twin and/or due to potential, excessive exposure to prenatal testosterone, which may influence behavior. Additionally, we hypothesized that OS males would be demasculinized with regard to religiousness when compared with SS males due to their growing up with a female co-twin.

\section{Materials and Methods}

\section{Participants}

An invitation to participate in a survey concerning attitudes and values was sent to 6,707 twins born from 1970 to 1989 in October 2009. The twins, who had previously given consent to participate in other surveys, were identified through the Danish Twin Registry (Skytthe et al., 2011). The zygosity status of the SS twin pairs was assessed through four ques- 
TABLE 1

Study Population of Danish Opposite-Sex and Same-Sex Twins Born 1970-1989

\begin{tabular}{|c|c|c|c|c|c|c|c|}
\hline \multirow[b]{2}{*}{ Characteristics } & \multicolumn{3}{|c|}{ Females } & \multicolumn{3}{|c|}{ Males } & \multirow[b]{2}{*}{ All Total } \\
\hline & Opposite-sex & Same-sex & All & Opposite-sex & Same-sex & All & \\
\hline$N(\%)$ & $408(13.6)$ & $1,383(46.1)$ & $1,791(59.8)$ & $350(11.7)$ & $856(28.6)$ & $1,206(40.2)$ & $2,997(100.0)$ \\
\hline Mean $(S D)$ age at participation & $29.3(6.3)$ & $30.0(6.0)$ & $29.8(6.03)$ & $29.2(6.2)$ & $30.1(6.2)$ & $29.8(6.2)$ & $29.8(6.1)$ \\
\hline \multicolumn{8}{|l|}{ Religious denominations } \\
\hline $\begin{array}{l}\text { The Danish National } \\
\text { Evangelical Church }\end{array}$ & $363(89.0)$ & $1.169(84.5)$ & $1,532(85.5)$ & $271(77.4)$ & $671(78.6)$ & $942(78.2)$ & $2,474(82.6)$ \\
\hline Catholic, Muslim, and Other ${ }^{a}$ & $3(0.7)$ & $51(3.7)$ & $54(3.0)$ & $7(2.0)$ & $10(1.2)$ & $17(1.4)$ & $71(2.4)$ \\
\hline Not a member & $42(10.3)$ & $163(11.8)$ & 205 (11.5) & $72(20.6)$ & $173(20.3)$ & $245(20.4)$ & $450(15.0)$ \\
\hline \multicolumn{8}{|l|}{$\begin{array}{l}\text { Education of the main provider } \\
\text { in childhood* }\end{array}$} \\
\hline Basic school & $41(10.1)$ & 189 (13.7) & $230(12.8)$ & $34(9.7)$ & $72(8.4)$ & $106(8.8)$ & $336(11.2)$ \\
\hline $\begin{array}{l}\text { Vocational school, secondary } \\
\text { education, and short higher } \\
\text { education }\end{array}$ & $204(50.0)$ & 719 (52.0) & $923(51.5)$ & $172(49.1)$ & 459 (53.6) & $631(52.3)$ & $1,554(51.9)$ \\
\hline $\begin{array}{l}\text { Medium higher education and } \\
\text { bachelor's degree }\end{array}$ & $93(22.8)$ & 266 (19.2) & $359(20.0)$ & 77 (22.0) & $191(22.3)$ & $268(22.2)$ & 627 (20.9) \\
\hline $\begin{array}{l}\text { Higher academic or } \\
\text { professional degree }\end{array}$ & $70(17.2)$ & 209 (15.1) & 279 (15.6) & 67 (19.1) & 134 (15.7) & $201(16.7)$ & 480 (16.0) \\
\hline
\end{tabular}

Note: a Jew, Hindu, Jehovah's witnesses, Buddhist etc.

$* p=.039$ for education of the main provider in childhood for OS versus SS twins for both sexes combined.

tions about the similarity of the twins, which is a method shown to have more than $95 \%$ agreement with zygosity based on genetic markers (Christiansen et al., 2003). The zygosity was known for all twins who participated except for one pair. Among the invited twins, 3,686 completed the questionnaire (response rate 55\%). The section of the questionnaire regarding religiousness and religious coping patterns was completed by 3,000 individuals (response rate $45 \%)$. The proportion of responders was similar between OS and SS twins. The proportion of twins for whom both twins in a pair completed these questions was $61.4 \%$. Of the 3,000 twins, we excluded two individuals because they were triplets, and one twin due to sex change. Thus, the study population consisted of 2,997 twins, 408 OS and 1,383 SS females, 350 OS and 856 SS males (Table 1). However, the RCOPE questions were only answered by 1,900 individuals (290 OS and 929 SS females, 208 OS and 473 SS males) who had experienced a crisis. Numbers (percentages) and age at participation for OS and SS twins for the different parts of the survey are presented in Supplementary Table 1.

\section{Materials}

This survey encompasses questions about, for example, health, lifestyle habits, socioeconomic status in childhood, educational level, and connection to the labor market, experiences with life crises, and relationship with the co-twin. Moreover, the questionnaire contains questions about religious beliefs and behavior, and questions about religious coping. The survey has been described in detail previously, and the present study is built on the same sample as in the two articles presented in the introduction (Hvidtjorn et al., 2013; 2014).

We applied la Cour and Hvidt's adaptation of sociolinguist Joshua A. Fishman's three conceptual dimensions of meaning: Cognition, Practice, and Importance (la Cour \& Hvidt, 2010). Cognition covers perceptions of beliefs, Practice covers frequency of church attendance and prayer, and Importance covers the importance of God and finding strength and comfort in religion. For the analyses on religiousness (Table 2) and religious coping (Table 3), the responses were categorized into 'yes', 'no' and 'do not know', where the 'yes' category included all levels of beliefs and frequencies of religious activities, and the 'no' category included those answering with absolute refusal. The questions, 'I have my own way of connecting with the divine without going to church or using religious services' and 'How important is God in your life?' had response options on a 10-point Likert scale ranging from 1, no, not at all, to 10, yes, definitely.

We used RCOPE for the assessment of positive and negative religious coping patterns. Responders who answered that they had experienced an event in their life that they considered a crisis were asked to answer the RCOPE questions, which were classified into six positive and seven negative coping strategies (Table 3). For the analyses assessing the use of religious coping associated with specific life crises (not shown), we collapsed the 13 items into one variable to investigate the overall use of coping. Responders who answered that they used the strategies presented in the RCOPE to some degree, quite a lot or very much according to a specific life crisis were included. In addition, we made one variable for the use of positive coping and one for the use of negative coping. Lastly, the seven specific life crises (death of a child, death of a mother, death of a father, death of a partner, divorce of parents, life-threatening disease, and serious chronic disease) were combined into one variable (not shown). For the questions about relationship with co-twin we combined the answers 'always', 'often', and 'sometimes' into one category (Supplementary Table 3). 
TABLE 2

Religiousness in Danish Opposite-Sex and Same-Sex Twins

\begin{tabular}{|c|c|c|c|c|c|}
\hline & Yes & No & Do not know & Crude OR $(95 \% \mathrm{Cl})$ & Adjusted $^{\mathrm{a}}$ OR $(95 \% \mathrm{Cl})$ \\
\hline \multicolumn{6}{|c|}{ Cognition } \\
\hline \multicolumn{6}{|c|}{ Do you believe in God? } \\
\hline OS females & $146(35.9)$ & $173(42.5)$ & $88(21.6)$ & & \\
\hline SS females & $510(36.9)$ & 537 (38.9) & $335(24.2)$ & $0.96(0.75-1.21)$ & $0.97(0.76-1.23)$ \\
\hline OS males & $92(26.3)$ & $199(56.9)$ & $59(16.9)$ & & \\
\hline SS males & $233(27.3)$ & $490(57.4)$ & $130(15.2)$ & $0.95(0.71-1.27)$ & $0.97(0.72-1.29)$ \\
\hline \multicolumn{6}{|c|}{ Do you believe in life after death? } \\
\hline SS females & $522(37.8)$ & $496(35.9)$ & $364(26.3)$ & $0.97(0.77-1.23)$ & $0.99(0.78-1.25)$ \\
\hline OS males & $74(21.1)$ & $193(55.1)$ & $83(23.7)$ & & \\
\hline SS males & $207(24.3)$ & $476(55.8)$ & $170(19.9)$ & $0.84(0.62-1.14)$ & $0.83(0.61-1.12)$ \\
\hline \multicolumn{6}{|c|}{ Do you believe in re-incarnation? } \\
\hline OS females & $70(17.2)$ & $230(56.5)$ & $107(26.3)$ & & \\
\hline SS females & $255(18.5)$ & $747(54.1)$ & $380(27.5)$ & $0.92(0.68-1.24)$ & $0.94(0.70-1.27)$ \\
\hline OS males & $37(10.6)$ & $246(70.3)$ & $67(19.1)$ & & \\
\hline SS males & $98(11.5)$ & $596(69.9)$ & $159(18.6)$ & $0.91(0.61-1.37)$ & $0.92(0.61-1.38)$ \\
\hline \multicolumn{6}{|c|}{ Practice } \\
\hline \multicolumn{6}{|c|}{ Do you ever attend religious services? } \\
\hline OS females & $298(73.0)$ & $109(26.7)$ & $1(0.3)$ & & \\
\hline SS females & $988(71.4)$ & $394(28.5)$ & $1(0.1)$ & $1.08(0.84-1.40)$ & $1.11(0.86-1.44)$ \\
\hline OS males & $214(61.1)$ & $135(38.6)$ & $1(0.3)$ & & \\
\hline SS males & $498(58.3)$ & $353(41.3)$ & $3(0.4)$ & $1.12(0.87-1.46)$ & $1.20(0.92-1.56)$ \\
\hline \multicolumn{6}{|c|}{$\begin{array}{l}\text { Do you ever pray to God outside } \\
\text { religious services? }\end{array}$} \\
\hline OS females & $221(54.2)$ & $181(44.4)$ & $6(1.5)$ & & \\
\hline SS females & $747(54.0)$ & 615 (44.5) & $21(1.5)$ & $1.01(0.80-1.26)$ & $1.00(0.80-1.26)$ \\
\hline OS males & $142(40.6)$ & $204(58.3)$ & $4(1.1)$ & & \\
\hline SS males & $318(37.3)$ & $528(62.0)$ & $6(0.7)$ & $1.15(0.88-1.49)$ & $1.16(0.89-1.50)$ \\
\hline \multicolumn{6}{|c|}{$\begin{array}{l}\text { Do you have your own way of } \\
\text { connecting with the divine? }\end{array}$} \\
\hline OS females & $301(74.0)$ & $75(18.4)$ & $31(7.6)$ & & \\
\hline SS females & 993 (71.9) & $246(17.8)$ & $143(10.4)$ & $1.11(0.86-1.44)$ & $1.14(0.88-1.47)$ \\
\hline OS males & $199(56.9)$ & 109 (31.1) & $42(12.0)$ & & \\
\hline OS females & $275(67.6)$ & $125(30.7)$ & $7(1.7)$ & & \\
\hline SS females & $948(68.6)$ & $404(29.2)$ & $30(2.2)$ & $0.95(0.75-1.22)$ & $0.96(0.75-1.22)$ \\
\hline OS males & $172(49.1)$ & $175(50.0)$ & $3(0.9)$ & & \\
\hline SS males & $438(51.4)$ & 405 (47.5) & $10(1.2)$ & $0.92(0.71-1.18)$ & $0.95(0.73-1.23)$ \\
\hline \multicolumn{6}{|c|}{$\begin{array}{l}\text { Do you find that you get strength and } \\
\text { comfort from religion? }\end{array}$} \\
\hline OS females & $92(22.6)$ & $250(61.4)$ & $65(16.0)$ & & \\
\hline SS females & $364(26.3)$ & $838(60.6)$ & $180(13.0)$ & $0.82(0.63-1.07)$ & $0.81(0.62-1.06)$ \\
\hline OS males & 73 (20.9) & $252(72.0)$ & $25(7.1)$ & & \\
\hline SS males & $151(17.7)$ & $638(74.8)$ & $64(7.5)$ & $1.23(0.89-1.69)$ & $1.23(0.89-1.69)$ \\
\hline \multicolumn{6}{|c|}{$\begin{array}{l}\text { Did God play a role in your life when } \\
\text { you were } 12 ?\end{array}$} \\
\hline OS females & $279(68.55)$ & $106(26.04)$ & $22(5.41)$ & & \\
\hline SS females & $971(70.26)$ & $325(23.52)$ & $86(6.22)$ & $0.92(0.72-1.18)$ & $0.91(0.71-1.16)$ \\
\hline OS males & $198(56.57)$ & $136(38.86)$ & $16(4.57)$ & & \\
\hline SS males & $467(54.75)$ & 351 (41.15) & $35(4.10)$ & $1.08(0.83-1.39)$ & $1.09(0.84-1.41)$ \\
\hline
\end{tabular}

\section{Statistical Analysis}

Odds ratios and 95\% confidence intervals (CIs) were calculated for females versus males and OS versus SS twins using logistic regression, and the CIs were adjusted for dependence within twin pairs. All analyses of OS and SS twins were stratified by sex, and both MZ and ssDZ twins were included in the SS twin groups. We adjusted all regression models of OS and SS twins for age at participation (continu- ous: exact age at November 1, 2009) and parental education (categorical: the highest obtained education for the primary provider), divided into four categories: basic school (7-10 years); secondary education (more than 11 years), vocational school, or short higher education; medium higher education or bachelor's degree; and higher academic or professional degree (Table 1). These possible confounders were adjusted for in the associations between OS/SS twins and 
TABLE 3

Use of Religious Coping in a Crisis

\begin{tabular}{|c|c|c|c|c|c|}
\hline & Yes & No & Do not know & Crude OR $(95 \% \mathrm{Cl})$ & Adjusted $^{\mathrm{a}}$ OR $(95 \% \mathrm{Cl})$ \\
\hline \multicolumn{6}{|c|}{ Positive dimensions } \\
\hline \multicolumn{6}{|c|}{$\begin{array}{l}\text { Looked for a stronger } \\
\text { connection with God }\end{array}$} \\
\hline OS females & $64(22.2)$ & $216(75.0)$ & $8(2.8)$ & & \\
\hline SS females & $222(21.9)$ & $674(73.1)$ & $46(5.0)$ & $1.02(0.74-1.41)$ & $1.03(0.74-1.42)$ \\
\hline OS males & $45(21.6)$ & $159(76.4)$ & 4 (1.9) & & \\
\hline SS males & $86(18.3)$ & $376(80.0)$ & $8(1.7)$ & $1.23(0.82-1.86)$ & $1.19(0.78-1.80)$ \\
\hline \multicolumn{6}{|c|}{ Sought God's love and care* } \\
\hline OS females & $84(29.2)$ & $196(68.1)$ & $8(2.8)$ & & \\
\hline SS females & $248(26.9)$ & $640(69.4)$ & $34(3.7)$ & $1.12(0.83-1.51)$ & $1.12(0.83-1.52)$ \\
\hline OS males & $40(19.2)$ & $164(78.9)$ & 4 (1.9) & & \\
\hline SS males & 89 (18.9) & $373(79.4)$ & $8(1.7)$ & $1.02(0.67-1.56)$ & $0.99(0.64-1.53)$ \\
\hline \multicolumn{6}{|c|}{$\begin{array}{l}\text { Sought help from God in letting } \\
\text { go of my anger** }\end{array}$} \\
\hline OS females & $60(20.8)$ & $217(75.4)$ & $11(3.8)$ & & \\
\hline SS females & $186(20.2)$ & $696(75.5)$ & $40(4.3)$ & $1.04(0.75-1.45)$ & $1.05(0.75-1.46)$ \\
\hline OS males & $34(16.4)$ & $170(81.7)$ & $4(1.9)$ & & \\
\hline SS males & $76(16.2)$ & 385 (81.9) & 9 (1.9) & $1.01(0.65-1.59)$ & $0.98(0.61-1.55)$ \\
\hline \multicolumn{6}{|c|}{$\begin{array}{l}\text { Tried to see how God might be } \\
\text { trying to strengthen me in } \\
\text { this situation }\end{array}$} \\
\hline OS females & $73(25.4)$ & 207 (71.9) & $8(2.8)$ & & \\
\hline SS females & $234(25.4)$ & $651(70.6)$ & $37(4.0)$ & $1.00(0.73-1.36)$ & $1.02(0.74-1.39)$ \\
\hline OS males & $53(25.5)$ & $150(72.1)$ & $5(2.4)$ & & \\
\hline SS males & $98(20.9)$ & $364(77.5)$ & $8(1.7)$ & $1.30(0.87-1.92)$ & $1.24(0.83-1.86)$ \\
\hline \multicolumn{6}{|c|}{ Asked forgiveness for my sins } \\
\hline OS females & $48(16.7)$ & $231(80.2)$ & $9(3.1)$ & & \\
\hline SS females & $118(12.8)$ & $777(84.3)$ & $27(2.9)$ & $1.36(0.94-1.97)$ & $1.39(0.95-2.02)$ \\
\hline OS males & $36(17.3)$ & $167(80.3)$ & $5(2.4)$ & & \\
\hline SS males & $62(13.2)$ & $403(85.7)$ & $5(1.1)$ & $1.38(0.88-2.16)$ & $1.36(0.86-2.15)$ \\
\hline \multicolumn{6}{|c|}{$\begin{array}{l}\text { Focused on religion to stop } \\
\text { worrying about my problems }\end{array}$} \\
\hline OS females & $23(8.0)$ & $259(89.9)$ & $6(2.1)$ & & \\
\hline SS females & $95(10.3)$ & $791(85.8)$ & $36(3.9)$ & $0.76(0.47-1.22)$ & $0.79(0.48-1.29)$ \\
\hline OS males & $17(8.2)$ & $183(88.0)$ & 8 (3.9) & & \\
\hline SS males & $38(8.1)$ & $423(90.0)$ & $9(1.9)$ & $1.01(0.56-1.84)$ & $0.94(0.51-1.75)$ \\
\hline \multicolumn{6}{|c|}{ Negative dimensions } \\
\hline \multicolumn{6}{|c|}{$\begin{array}{l}\text { Wondered why God had } \\
\text { abandoned me }\end{array}$} \\
\hline OS females & $31(10.8)$ & $250(86.8)$ & $7(2.4)$ & & \\
\hline SS females & $123(13.3)$ & $777(84.3)$ & $22(2.4)$ & $0.78(0.51-1.19)$ & $0.80(0.52-1.23)$ \\
\hline OS males & $16(7.7)$ & $186(89.4)$ & $6(2.9)$ & & \\
\hline SS males & $55(11.7)$ & $411(87.5)$ & $4(0.9)$ & $0.63(0.35-1.13)$ & $0.63(0.35-1.14)$ \\
\hline \multicolumn{6}{|c|}{$\begin{array}{l}\text { Felt punished by God for my } \\
\text { lack of devotion }\end{array}$} \\
\hline OS females & $17(5.9)$ & $263(91.3)$ & $8(2.8)$ & & \\
\hline SS females & $57(6.2)$ & $842(91.3)$ & $23(2.5)$ & $0.95(0.54-1.67)$ & $1.05(0.60-1.86)$ \\
\hline OS males & $10(4.8)$ & $194(93.3)$ & $4(1.9)$ & & \\
\hline SS males & $27(5.7)$ & $438(93.2)$ & $5(1.1)$ & $0.83(0.39-1.76)$ & $0.86(0.40-1.84)$ \\
\hline \multicolumn{6}{|c|}{$\begin{array}{l}\text { Wondered what I did for God to } \\
\text { punish me }\end{array}$} \\
\hline OS females & $50(17.4)$ & $232(80.6)$ & $6(2.1)$ & & \\
\hline SS females & $160(17.4)$ & $738(80.0)$ & $24(2.6)$ & $1.00(0.71-1.42)$ & $1.02(0.71-1.45)$ \\
\hline OS males & $28(13.5)$ & $176(84.6)$ & 4 (1.9) & & \\
\hline SS males & $66(14.0)$ & $399(84.9)$ & $5(1.1)$ & $0.95(0.59-1.54)$ & $0.93(0.57-1.52)$ \\
\hline \multicolumn{6}{|c|}{ Questioned God's love for me } \\
\hline OS females & $30(10.4)$ & $251(87.2)$ & $7(2.4)$ & & \\
\hline SS females & $106(11.5)$ & $788(85.5)$ & $28(3.0)$ & $0.90(0.58-1.38)$ & $0.92(0.59-1.43)$ \\
\hline OS males & $19(9.1)$ & $185(88.9)$ & $4(1.9)$ & & \\
\hline SS males & $54(11.5)$ & $412(87.7)$ & $4(0.9)$ & $0.77(0.44-1.35)$ & $0.74(0.43-1.28)$ \\
\hline \multicolumn{6}{|c|}{$\begin{array}{l}\text { Wondered whether my church } \\
\text { had abandoned me*** }\end{array}$} \\
\hline OS females & $3(1.0)$ & $277(96.2)$ & $8(2.8)$ & & \\
\hline SS females & $18(2.0)$ & $877(95.1)$ & $27(2.9)$ & $0.53(0.15-1.81)$ & $0.52(0.15-1.84)$ \\
\hline OS males & $7(3.4)$ & $197(94.7)$ & 4 (1.9) & & \\
\hline SS males & $16(3.4)$ & $450(95.7)$ & $4(0.9)$ & $0.99(0.40-2.44)$ & $0.98(0.39-2.44)$ \\
\hline \multicolumn{6}{|c|}{$\begin{array}{l}\text { Believed the devil was } \\
\text { responsible for my situation }\end{array}$} \\
\hline OS females & $14(4.9)$ & $268(93.1)$ & $6(2.1)$ & & \\
\hline SS females & $28(3.0)$ & $870(94.4)$ & $24(2.6)$ & $1.63(0.85-3.14)$ & $1.69(0.87-3.29)$ \\
\hline OS males & $6(2.9)$ & $198(95.2)$ & 4 (1.9) & & \\
\hline SS males & $25(5.3)$ & $441(93.8)$ & $4(0.9)$ & $0.53(0.21-1.34)$ & $0.49(0.19-1.30)$ \\
\hline
\end{tabular}


TABLE 3

Continued

\begin{tabular}{|c|c|c|c|c|c|}
\hline & Yes & No & Do not know & Crude OR $(95 \% \mathrm{Cl})$ & Adjusted $^{\text {a }}$ OR $(95 \% \mathrm{Cl})$ \\
\hline \multicolumn{6}{|c|}{ Questioned the power of God } \\
\hline OS females & $47(16.3)$ & $232(80.6)$ & $9(3.1)$ & & \\
\hline SS females & $150(16.3)$ & 732 (79.4) & $40(4.3)$ & $1.00(0.70-1.44)$ & $1.04(0.72-1.50)$ \\
\hline OS males & $27(13.0)$ & $172(82.7)$ & $9(4.3)$ & & \\
\hline SS males & 70 (14.9) & 393 (83.6) & $7(1.5)$ & $0.85(0.53-1.38)$ & $0.81(0.49-1.32)$ \\
\hline $\begin{aligned} & \text { Note: Values } \\
& \text { oppos } \\
& \text { know } \\
& \text { aAdjus } \\
& \\
&{ }^{*} \text { Crud } \\
&{ }^{* *} \text { Cruo } \\
&\end{aligned}$ & $\begin{array}{l}\text { stratified by } \\
\text { (SS) twins ar } \\
\text { hen estimatir } \\
\text { and parental } \\
\text {, p value still } \\
\text { ), } p \text { value no } \\
\text { 2) } p \text { value } n\end{array}$ & $\begin{array}{l}\text { and co-twin s } \\
\text { ng to some o } \\
\text { tion of the ma } \\
\text { cant after cor } \\
r \text { significant a } \\
\text { r significant }\end{array}$ & $\begin{array}{l}\text { well as crude a } \\
\text { or very much cc } \\
\text { vider in childhoc } \\
\mathrm{g} \text { for multiple tes } \\
\text { rrecting for mult }\end{array}$ & $\begin{array}{l}\text { justed odds ratios wi } \\
\text { ed with not at all or } \\
\text { sting. }\end{array}$ & $\begin{array}{l}\text { confidence intervals for } \\
\text { know. The no and do not }\end{array}$ \\
\hline
\end{tabular}

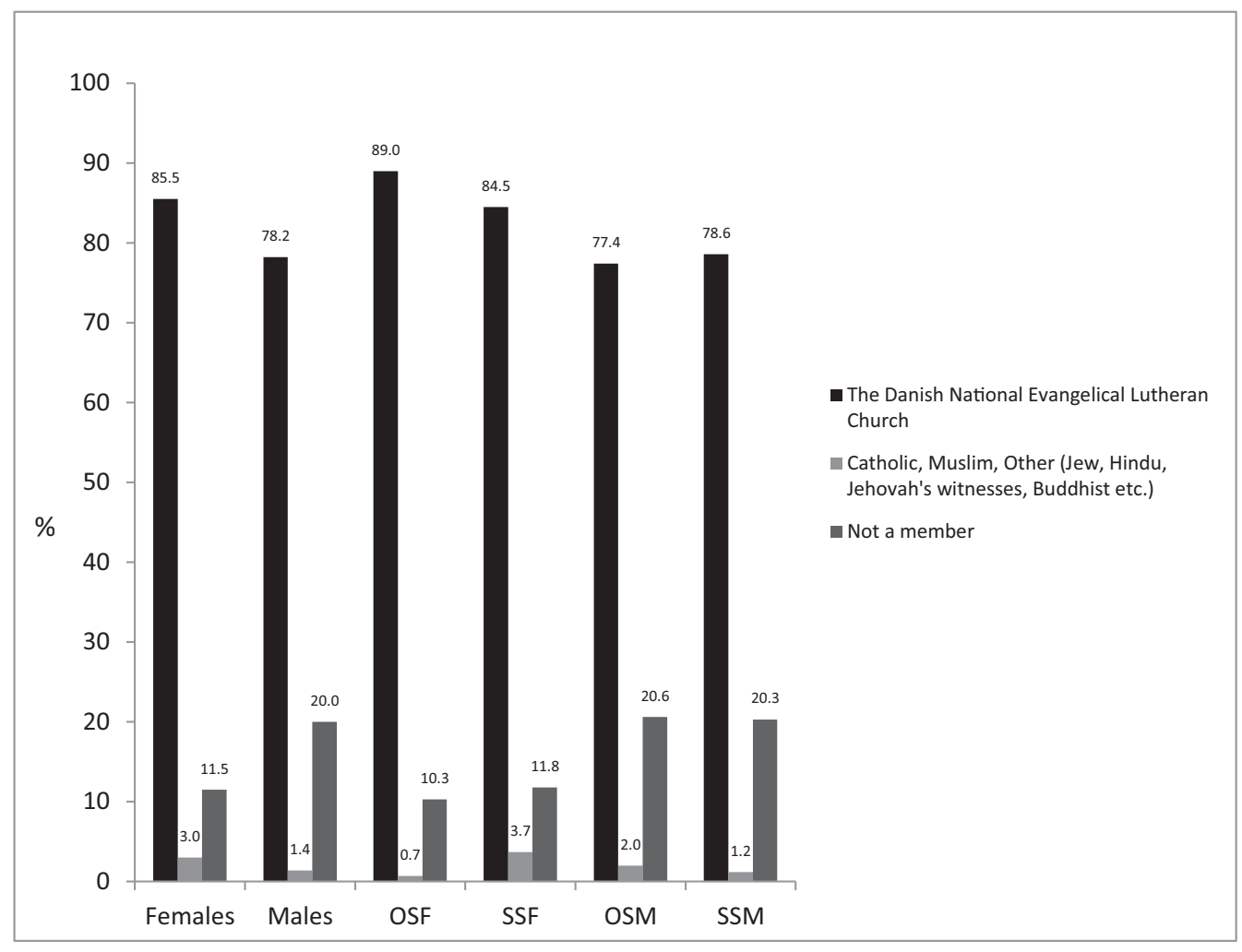

\section{FIGURE 1}

Religious denominations for Danish twins stratified by sex and co-twins sex.

Note: Proportions of religious denominations for females and males, opposite-sex females (OSF), same-sex females (SSF), opposite-sex males (OSM), and same-sex males (SSM).

religiousness. Additionally, we also investigated the raw associations between the potential confounding variables and membership of the Danish National Evangelical Lutheran Church (Supplementary Table 2). We also tested whether educational level of participants, having experienced a crisis, and self-rated health was different between OS and SS twins. This was not the case, and therefore these variables were not included as confounders in the regression model. Regression models comparing females and males were adjusted for self-rated health, and having experienced a crisis, educational level and parental education because these variables were significantly different between the sexes (not shown). In Tables 2 and 3, both crude and adjusted ORs are presented. However, in the results section we have only described the adjusted ORs. The ORs are not shown in the figures.

For the statistical analyses of religious denominations, members of the Danish National Evangelical Lutheran Church and other religious denominations were first combined and tested against 'not a member'. Second, we investigated members of the Danish National Evangelical Lutheran Church and other religious denominations 
separately. For the analyses of church attendance, the twins attending church at least once a month or on specific holidays were combined into one group which was compared with the 'never' group. The two groups were also investigated separately. For religiousness (Table 2) and religious coping (Table 3 ) the 'yes' categories were compared with the 'no' and 'do not know' categories combined for each question. To test the robustness of the results, we used a multinomial regression model to check whether the 'no' category differed from the 'yes' category. This did not change the significance of the results (not shown). Moreover, we repeated all analyses excluding the MZ twins (not shown), and this did not change the significance of the results. The significant $p$ values were adjusted for multiple testing by Bonferroni correction. For the logistic regression analyses of relationship with co-twin, the answers always, often and sometimes were compared with the categories rare and never combined (Supplementary Table 3).

\section{Results \\ Sex Differences}

Overall, most of the responders were members of the Danish National Evangelical Lutheran Church (82.6\%; Table 1), which is just $1 \%$ higher than the national level (Lodberg, 2009). Figure 1 shows the proportion of religious denominations among the Danish twins. When comparing all members of a religious denomination with those not being a member, a significant sex difference was found, with more females than males being members of either the Danish National Evangelical Lutheran Church or other religious denominations, $\mathrm{OR}=1.98$ (95\% CI 1.56-2.50). When stratified by religious denomination we found, as shown in a recent Danish study (Hvidtjorn et al., 2014), that a higher proportion of females than males are members of the Danish National Evangelical Lutheran Church, OR = 1.64 (95\% CI 1.31-2.05) and likewise that more females than males are members of other religious denominations, $\mathrm{OR}=2.13$ (95\% CI 1.17-3.89). In Figure 2, the frequency of church attendance in childhood and adulthood is presented. In adulthood, a higher proportion of females than males reported attending church, OR $=1.77$ (95\% CI 1.49-2.10). This was also the case for attending church on specific holidays, OR $=1.71$ (95\% CI 1.45-2.02), but no sex difference was found for those attending church at least once a month. More females than males reported attending church at the age of $12, \mathrm{OR}=1.31$ (95\% CI 1.10-1.56). A sex difference was also found for those attending church at least once a month, OR $=1.32$ (95\% CI 1.01-1.71), but the significance disappeared after correcting for multiple testing. No sex difference was found for those attending church on specific holidays. With regard to religiousness (Table 2), all sex differences were significant, both crude and adjusted for self-rated health, having experienced a crisis, educational level, and parental education, with females being more religious than males, $p$ values $<.05$ (results not shown). Also, more females than males reported that God was important in their life at age 12 , OR $=1.90(95 \%$ CI 1.62-2.24). When asked in more detail about beliefs and perceptions of God, a similar pattern was found, with fewer females than males not believing in God or in doubt, and more females than males believing in some sort of spirit or in God (results not shown). For religious coping, significant sex differences were found for three questions: More females than males sought God's love and care and sought help from God in letting go of their anger, whereas fewer females than males wondered whether their church had abandoned them (Table 3). For the use of religious coping with respect to specific crises, no significant sex differences were found. An indication that more females than males used the coping strategies was observed $(\mathrm{OR}=1.20,95 \%$ CI $0.89-1.60)$. This was the case for both positive, $\mathrm{OR}=1.15$ (95\% CI $0.85-1.56)$ and negative 1.24 (95\% CI 0.91-1.69) religious coping (results not shown, available on request).

\section{OS Versus SS Females}

Overall, there was no significant difference between OS and SS females for being members of a religious denomination compared with being not a member, $\mathrm{OR}=$ 1.26 (95\% CI 0.87-1.84). However, we found that more OS than SS females were members of the Danish National Evangelical Lutheran Church, OR $=1.61$ (95\% CI 1.122.30) and fewer OS than SS females were Catholic, Muslim or belonged to other religious denominations, $\mathrm{OR}=$ 0.18 (95\% CI 0.06-0.61; Figure 1). For church attendance (Figure 2), the proportions of OS and SS females who answered that they attended church at least once a month or on specific holidays were similar, $\mathrm{OR}=1.12(0.86-1.45)$. This was also the case for both groups at age $12, \mathrm{OR}=0.99$ (0.77-1.28), and when investigating the groups separately. No differences were found in religiousness for OS and SS female twins either for Cognition, Practice, or Importance (Table 2). Also, when asked in more detail about beliefs and perceptions of God, no significant differences were found (results not shown). No consistent pattern was found between OS and SS females with regard to the use of religious coping in a crisis (Table 3). No significant differences were found either for the use of the RCOPE strategies with regard to the seven specific crises or when all crises were combined (results not shown).

\section{OS Versus SS Males}

We found no significant differences in religious denominations between OS and SS males either for all religious denominations combined, $\mathrm{OR}=1.02$ (95\% CI 0.74-1.41) or for membership of the Danish National Evangelical Lutheran Church and other religious denominations when investigated separately (Figure 1). For church attendance in adulthood, no significant differences between OS and SS males were found, $\mathrm{OR}=1.20$ (95\% CI 0.92-1.56). Nor did 


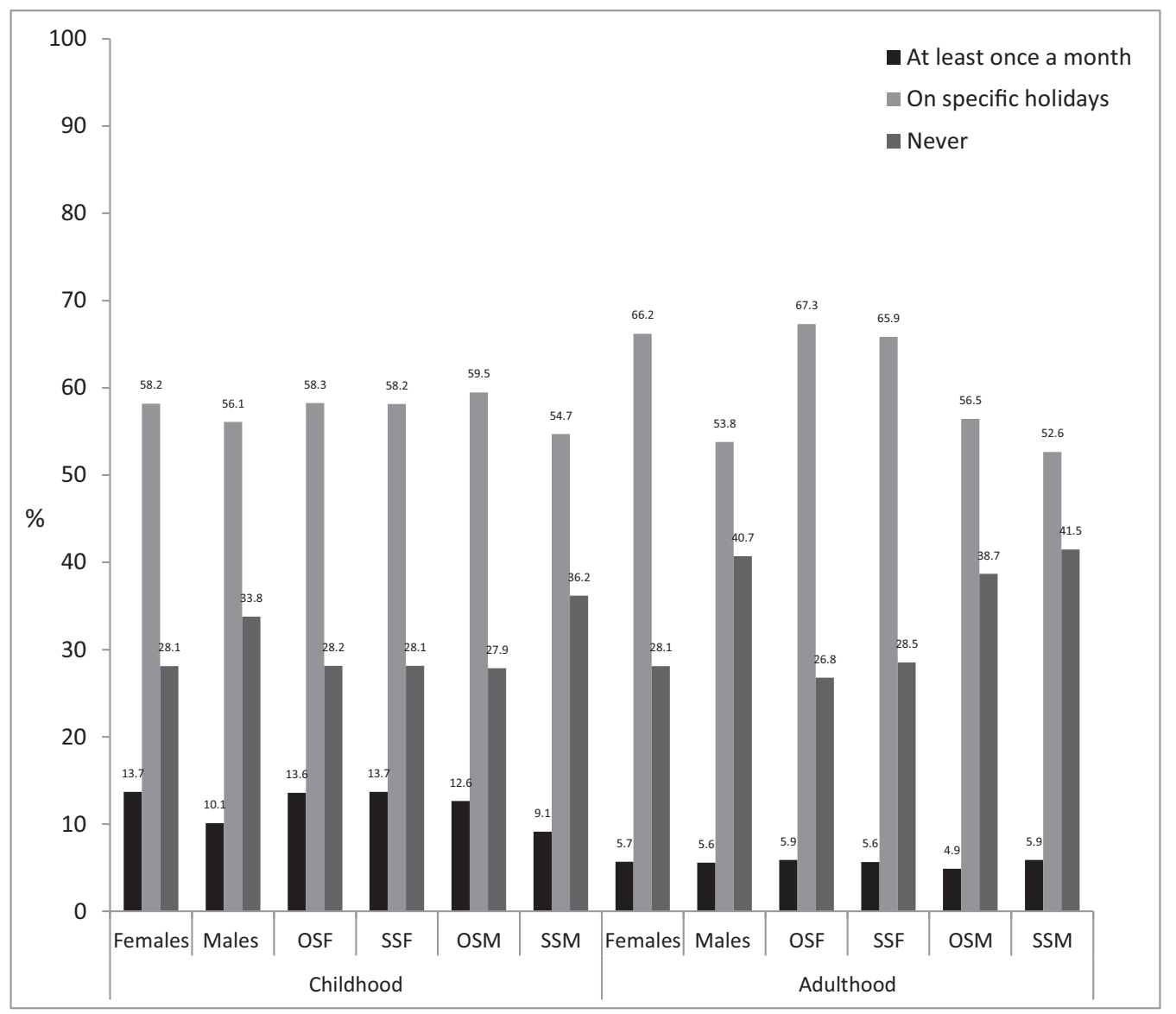

\section{FIGURE 2}

Church attendance at childhood and at adulthood for Danish twins stratified by sex and co-twins sex.

Note: Proportions of church attendance for females and males, opposite-sex females (OSF), same-sex females (SSF), opposite-sex males (OSM), and same-sex males (SSM).[COMP: Please take care while formatting figures. As the Note portion of the figure has been retained in this doc file, so please don't retain it in the artwork/PDF.]

we find any significant difference between the OS and SS males for attending church once a month, $\mathrm{OR}=0.80(95 \%$ CI 0.44-1.44) or on specific holidays, $\mathrm{OR}=1.25(95 \% \mathrm{CI}$ 0.97-1.63). However, significantly more OS than SS males reported having attended church at least once a month or on specific holidays at age 12 , OR $=1.51$ (95\% CI 1.142.00). This tendency persisted also when comparing the proportions attending church once a month, $\mathrm{OR}=1.40$ (95\% CI $0.93-2.13)$ and on specific holidays, $\mathrm{OR}=1.26$ (95\% CI 0.97-1.64). No significant differences were found for religiousness between OS and SS males or for the role of God at age 12 (Table 2). However, there was a tendency towards more OS than SS males answering 'yes' to some of the questions regarding Practice and Importance: attending religious services ( $61.1 \%$ vs. $58.3 \%)$, praying to God outside religious services (40.6\% vs. $37.3 \%)$, and finding strength and comfort from religion ( $20.9 \%$ vs. $17.7 \%)$. When asked in more detail about their beliefs and perceptions of God, similar proportions were found for OS and SS males (results not shown). Among male responders who completed the
RCOPE questions ( $n=681$ ) we found an indication of a higher proportion of OS than SS males using some of the positive coping strategies: $21.6 \%$ versus $18.3 \%$ looked for a stronger connection with God, $25.5 \%$ versus $20.9 \%$ tried to see how God might strengthen them in the situation, and $17.3 \%$ versus $13.2 \%$ asked forgiveness for their sins. Conversely, a tendency was found towards fewer OS than SS males employing negative coping strategies (Table 3 ). For the use of RCOPE with regard to the specific crises, we found a tendency towards more OS than SS males using the positive coping strategies, $\mathrm{OR}=1.20$ (95\% CI 0.70-2.06), and fewer OS than SS males using the negative coping strategies, $\mathrm{OR}=0.67$ (95\% CI 0.36-1.24) when all crises were combined; however, the differences were non-significant (results not shown).

\section{Age at Participation and Parental Education}

The raw associations between the potential confounding variables and membership of the Danish National Evangelical Lutheran Church showed an indication towards higher 
membership rates with increasing age for both sexes; however, the differences were non-significant (Supplementary Table 2). We found lower membership rates with increasing education of the main provider in childhood for both sexes, significant for females where the main provider had medium higher education or a Bachelor's degree, $\mathrm{OR}=$ 0.39 (95\% CI 0.22 to 0.70$)$ as well as a higher academic or professional degree, $\mathrm{OR}=0.45$ (95\% CI 0.24 to 0.82 ). When the associations were adjusted for the other variable and for OS/SS twin status, the results were similar (not shown).

\section{Relationship With Co-Twin}

With regard to relationship with the co-twin in childhood, we found that significantly more SS than OS twins of both sexes shared the same room, had the same friends, shared the same interests, and were treated in the same way by their parents in childhood (Supplementary Table 3). Conversely, more OS than SS males went to the same class. This tendency was also present for females, but non-significant (Supplementary Table 3). SS males had lived significantly longer with their co-twin compared with OS males, mean difference (in years) $=2.08$ (95\% CI 0.32 to 3.84$)$. The same pattern was present for females, mean difference $=$ 2.90 (95\% CI -3.75 to 9.55; not shown).

\section{Discussion}

In this population-based survey study of Danish twins aged 20-40 years, we confirmed the previously found sex differences in religiousness. We hypothesized that OS female twins would be masculinized in religiousness due to their growing up with a male co-twin and/or due to potential, excessive exposure to prenatal testosterone that may influence behavior. However, we did not find any significant differences in religiousness or in religious coping between OS and SS females. Contrary to expectations, we found that more OS than SS females were members of the Danish National Evangelical Lutheran Church; however, fewer OS than SS females were members of other religious denominations such as Catholic or Muslim denominations, but the difference was small ( $0.7 \%$ vs. $3.7 \%)$. In addition, when comparing the answers of the OS males with those of the SS males, we found that they were similar for most of the items of religiousness except that OS males had higher rates of church attendance at age 12 . The result would have been in accordance with what we hypothesized if OS males had displayed a more feminine pattern of religiousness; however, in adulthood the rates of church attendance were similar for OS and SS males.

Despite religiousness being largely influenced by shared environmental factors (Hvidtjorn et al., 2013) and despite the known sex differences (Trzebiatowska \& Bruce, 2012), we did not find that religiousness was influenced by having an OS versus having an SS co-twin, either for females or for males in most of the items of religiousness. A possible reason could be that Denmark is a secular society where religion plays a minor role in public life. Studies suggest that religion is rarely articulated, even within families, and it is rarely part of the family discourse (Grube \& Munksgaard, 2014; Rosen, 2009; Zuckerman, 2008). Thus, it is possible that socialization effects that may be experienced by co-twins would be diminished for religiousness. However, for the use of religious coping with regard to a crisis, we found an indication towards more females than males using the RCOPE strategies. This was the case for both positive and negative religious coping. We found a tendency towards more OS than SS males using the positive coping strategies and fewer OS than SS males using the negative coping strategies. Thus, only the indications for positive coping follow the typical pattern of male-female differences, but the results indicate that being an OS twin male constitutes an advantage with regard to religious coping. This is in line with the Finnish study, which also found positive effects of being an OS twin (Pulkkinen et al., 2003). Conversely, a recent study of 140 Hungarian twin pairs concluded that females had more advantages from being a twin than did males; however, the only significant difference between the sexes concerned the sentiment of feeling special (Hegedus et al., 2014).

Socialization effects could also be due to adult-child interactions (Grube \& Munksgaard, 2014). A previous study examining genetic and environmental influences on a selfreport measure of religiousness in a sample of adopted and non-adopted adolescents and their parents confirmed the large environmental effects on religiousness, which did not vary significantly by gender (Koenig et al., 2009). However, of the shared environmental effects, $68 \%$ was attributable to parental transmission effects, which was larger for mothers than for fathers (Koenig et al., 2009). Thus, the major source for the shared environmental influence appears to be parents rather than twins/siblings. From the Danish web-based survey we also analyzed the questions regarding relationship with a co-twin in childhood, and they show very high proportions of both OS and SS twins answering that they share the same room, have the same friends, go to the same class, and have the same interests. Furthermore, to the question 'Did your parents treat you in the same way?' between $81.6 \%$ and $93.8 \%$ of the twins answered that this was the case always, often or sometimes. However, SS twins were generally treated more similar than OS twins for both sexes except that more SS than OS male twins were separated into different classes in school. For females, the proportions were similar (Supplementary Table 3). If females displayed more adaptive behavior than males, which is a consistent finding in the literature (Maughan et al., 2004), a possible explanation for the finding that OS males have higher rates of church attendance in childhood than SS males could be that parents of OS twins are more likely to take their children to church compared with parents of two male twins. 
This study did not provide evidence that behavioral effects of prenatal testosterone influence religiousness. Especially OS female twins are assumed to be exposed to higher levels of testosterone in utero compared with SS females, and the effect is suggested to be larger than any possible effects of prenatal hormone transfer among OS and SS males (Cohen-Bendahan et al., 2005; Tapp et al., 2011). We did not find any significant differences between OS and SS females in any of the items of religiousness or religious coping, suggesting no evidence for the TTT hypothesis in agreement with recent studies (Ahrenfeldt, Skythe et al., 2015; Korsoff et al., 2014; Sorensen et al., 2013). On the other hand, our results could be interpreted as falsifying the TTT hypothesis. Evidence for this hypothesis is based on animal studies, and if masculinization or feminization effects exist, they might be manifested only in clinical samples (Hines, 2011). The literature comparing OS and SS twins remains inconsistent, and except for studies in sensation seeking (Resnick et al., 1993; Slutske et al., 2011), there is sparse evidence for prenatal hormonal transfer in twin studies investigating behavioral traits (Tapp et al., 2011).

Many factors may influence religiousness. Evidence suggests that age influences religiousness (Deaton, 2009; Levin et al., 2011; Moberg, 2012) and that parental education is associated with religiousness in the offspring as well (McFadden, 1995; Zuckerman et al., 2013). In this study, we found an indication towards higher membership rates of the Danish National Evangelical Lutheran Church with increasing age for both sexes (Supplementary Table 2), and we demonstrated that age at participation was higher among SS than among OS twins (Table 1). Also, we showed a tendency towards lower rates of membership of the Danish National Evangelical Lutheran Church with higher education of the main provider in childhood for both sexes (Supplementary Table 2), and that parents of OS twins had slightly higher education than parents of SS twins (Table 1), which has also been shown in a previous Danish twin study (Ahrenfeldt, Petersen et al., 2015). However, only small differences were present between crude and adjusted estimates, indicating that the small differences in age and parental education had a minor influence.

The strengths of the present study were the detailed information about religiousness through many different questions, resulting in a thorough investigation of a possible masculinization of OS females or a demasculinization of OS males. In addition, all twins in this sample except for one pair had known zygosity, thus making it possible to repeat all analyses excluding the $M Z$ twins and to make the most appropriate test of the TTT hypothesis, which is a comparison between ssDZ and OS twins (Cohen-Bendahan et al., 2005). Moreover, we had information on important potential confounders for the majority of the twins.

The low response rate of $55 \%$ for the overall web-based questionnaire concerning attitudes and values and of $45 \%$ for the section regarding beliefs and behavior was a lim- itation in this study. However, selection bias arises when the association between exposure and outcome differs for those who participate and those who do not participate in the study (Rothman, 2002). For the web-based questionnaire there were fewer responders among OS than among SS females (55.9\% vs. $60.4 \%$ ) and similar proportions were found for OS and SS males (49.6\% vs. 50.0\%). However, both self-rated health and educational status, a proxy for social status that is strongly associated with health (Euteneuer, 2014) was similar between the OS and the SS twins who participated in the survey, and we have no reason to believe that there are any important differences between the OS and SS twins who participated and those who did not participate, which may have influenced the results. Importantly, the proportion of responders was similar between OS and SS twins who answered the questions about beliefs and existential values and among those who answered the RCOPE questions. However, the low response rate resulted in limited power, especially in the analyses investigating religious coping. Thus, some of the tendencies found in this study might have been statistically significant if the sample size had been larger.

In conclusion, this study did not provide evidence for masculinization of female twins with male co-twins with regard to religiousness. Religiousness of male twins was not dependent on whether they had a twin sister or a twin brother except that males with female co-twins had higher rates of church attendance in childhood. Further studies with larger sample sizes should investigate sex differences as well as differences between OS and SS twins with regard to religious coping.

\section{Acknowledgments}

This study was supported by research Grants from the National Institute on Aging (NIA-PO1-AG08761, NIAP01AG031719).

\section{Supplementary Material}

To view supplementary material for this article, please visit http://dx.doi.org/10.1017/thg.2015.92.

\section{References}

Ahrenfeldt, L., Petersen, I., Johnson, W., \& Christensen, K. (2015). Academic performance of opposite-sex and samesex twins in adolescence: A Danish national cohort study. Hormones and Behavior, 69, 123-131.

Ahrenfeldt, L. J., Skytthe, A., Moller, S., Czene, K., Adami, H. O., Mucci, L. A., ... Lindahl-Jacobsen, R. (2015). Risk of sex-specific cancers in opposite-sex and same-sex twins in Denmark and Sweden. Cancer Epidemiology, Biomarkers \& Prevention, 24, 1622-1628.

Christiansen, L., Frederiksen, H., Schousboe, K., Skytthe, A., von Wurmb-Schwark, N., Christensen, K., \& Kyvik, K. (2003). Age- and sex-differences in the validity of 
questionnaire-based zygosity in twins. Twin Research, 6, 275-278.

Cohen-Bendahan, C. C., van de Beek, C., \& Berenbaum, S. A. (2005). Prenatal sex hormone effects on child and adult sex-typed behavior: Methods and findings. Neuroscience \& Biobehavioral Reviews, 29, 353-384.

Deaton, A. (2009). Aging, religion, and health (NBER Working Paper No. 15271). Cambridge, MA: National Bureau of Economic Research.

Elizabeth, P. H., \& Green, R. (1984). Childhood sex-role behaviors: Similarities and differences in twins. Acta Geneticae Medicae et Gemellologiae (Roma), 33, 173-179.

Euteneuer, F. (2014). Subjective social status and health. Current Opinion in Psychiatry, 27, 337-343.

Grube, K., \& Munksgaard, S. S. (2014). Why do you want to be ecclesiastically confirmed? Aarhus: Center for Youth Studies. Retrieved from http://www.cur.nu/index.php?id= 37982\&tx_ttnews[tt_news] $=11484 \&$ cHash $=$ b6559f94e2a6 5f91ea55a23e39167fa2.

Hegedus, R., Pari, A., Drjenovszky, Z., \& Konya, H. (2014). Twinship as a resource: Zygosity- and gender-based comparison of twins' attitudes toward twinship. Twin Research and Human Genetics, 17, 376-382.

Heil, M., Kavsek, M., Rolke, B., Beste, C., \& Jansen, P. (2011). Mental rotation in female fraternal twins: Evidence for intra-uterine hormone transfer? Biological Psychology, 86, 90-93.

Henderson, B. A., \& Berenbaum, S. A. (1997). Sex-typed play in opposite-sex twins. Developmental Psychobiology, 31, 115-123.

Hines, M. (2011). Gender development and the human brain. Annual Review of Neuroscience, 34, 69-88.

Hvidtjorn, D., Hjelmborg, J., Skytthe, A., Christensen, K., \& Hvidt, N. C. (2014). Religiousness and religious coping in a secular society: The gender perspective. Journal of Religion and Health, 53, 1329-1341.

Hvidtjorn, D., Petersen, I., Hjelmborg, J., Skytthe, A., Christensen, K., \& Hvidt, N.C. (2013). Familial resemblance in religiousness in a secular society: A twin study. Twin Research and Human Genetics, 1-10.

Koenig, L. B., McGue, M., \& Iacono, W. G. (2008). Stability and change in religiousness during emerging adulthood. Developmental Psychology, 44, 532-543.

Koenig, L. B., McGue, M., \& Iacono, W. G. (2009). Rearing environmental influences on religiousness: An investigation of adolescent adoptees. Personality and Individual Differences, 47, 652-656.

Koenig, L. B., McGue, M., Krueger, R. F., \& Bouchard, T. J., Jr. (2005). Genetic and environmental influences on religiousness: Findings for retrospective and current religiousness ratings. Journal of Personality, 73, 471-488.

Korsoff, P., Bogl, L. H., Korhonen, P., Kangas, A. J., Soininen, P., Ala-Korpela, M., ... Kaprio, J. (2014). A comparison of anthropometric, metabolic, and reproductive characteristics of young adult women from opposite-sex and same-sex twin pairs. Frontiers in Endocrinology (Lausanne), 5, 28. la Cour, P., \& Hvidt, N. C. (2010). Research on meaningmaking and health in secular society: Secular, spiritual and religious existential orientations. Social Science \& Medicine, $71,1292-1299$.

Laffey-Ardley, S., \& Thorpe, K. (2006). Being opposite: is there advantage for social competence and friendships in being an opposite-sex twin? Twin Research and Human Genetics, 9, 131-140.

Levin, J., Chatters, L., \& Taylor, R. (2011). Theory in religion, aging, and health: An overview. Journal of Religion \& Health, 50, 389-406.

Lodberg, P. (2009). The Danish national church: Center for contemporary religion, religion in Denmark. Aarhus: Aarhus University. Retrieved from http://samtidsreligion.au.dk/ religion-i-danmark/rel-aarbog09/pl/.

Loehlin, J. C., \& Martin, N. G. (2000). Dimensions of psychological masculinity-femininity in adult twins from opposite-sex and same-sex pairs. Behavior Genetics, 30, 1928.

Maughan, B., Rowe, R., Messer, J., Goodman, R., \& Meltzer, H. (2004). Conduct disorder and oppositional defiant disorder in a national sample: Developmental epidemiology. Journal of Child Psychology and Psychiatry, 45, 609-621.

McFadden, S. H. (1995). Religion and well-being in aging persons in an aging society. Journal of Social Issues, 51, 161-175.

McHale, S. M., Updegraff, K. A., Helms-Erikson, H., \& Crouter, A. C. (2001). Sibling influences on gender development in middle childhood and early adolescence: A longitudinal study. Developmental Psychology, 37, 115125.

Miller, E. M. (1994). Prenatal sex hormone transfer: A reason to study opposite-sex twins. Personality and Individual Differences, 17, 511-529.

Miller, E. M., \& Martin, N. (1995). Analysis of the effect of hormones on opposite-sex twin attitudes. Acta Geneticae Medicae et Gemellologiae (Roma), 44, 41-52.

Moberg, D. O. (2012). Aging and spirituality: Spiritual dimensions of aging theory, research, practice, and policy. Routledge: New York.

Neyer, F. J. (2002). Twin relationships in old age: A developmental perspective. Journal of Social and Personal Relationships, 19, 155-177.

Pargament, K. I. (1997). The psychology of religion and coping. New York: The Guildford Press.

Pargament, K. I., Koenig, H. G., \& Perez, L. M. (2000). The many methods of religious coping: Development and initial validation of the RCOPE. Journal of Clinical Psychology, 56, 519-543.

Phoenix, C. H. (2009). Organizing action of prenatally administered testosterone propionate on the tissues mediating mating behavior in the female guinea pig. Hormones and Behavior, 55, 566.

Phoenix, C. H., Goy, R. W., Gerall, A. A., \& Young, W. C. (1959). Organizing action of prenatally administered testosterone propionate on the tissues mediating mating behavior in the female guinea pig. Endocrinology, 65, 369-382. 
Pulkkinen, L., Vaalamo, I., Hietala, R., Kaprio, J., \& Rose, R. J. (2003). Peer reports of adaptive behavior in twins and singletons: Is twinship a risk or an advantage? Twin Research, 6, 106-118.

Resnick, S. M., Gottesman, I. I., \& McGue, M. (1993). Sensation seeking in opposite-sex twins: An effect of prenatal hormones? Behavior Genetics, 23, 323-329.

Rodgers, C., Fagot, B., \& Winebarger, A. (1998). Gender-typed toy play in dizygotic twin pairs: A test of hormone transfer theory. Sex Roles, 39, 173-184.

Rose, R. J., Kaprio, J., Winter, T., Dick, D. M., Viken, R. J., Pulkkinen, L., \& Koskenvuo, M. (2002). Femininity and fertility in sisters with twin brothers: Prenatal androgenization? Cross-sex socialization? Psychological Science, 13, 263267.

Rosen, I. (2009). I'm a believer - but I'll be damned if I'm religious. Belief and religion in the Greater Copenhagen Area - a focus group study. Lund, Sweden: Lunds University.

Rothman, K. J. (2002). Epidemiology: An introduction. New York: Oxford University Press.

Rust, J., Golombok, S., Hines, M., Johnston, K., \& Golding, J. (2000). The role of brothers and sisters in the gender development of preschool children. Journal of Experimental Child Psychology, 77, 292-303.

Rutter, M., \& Redshaw, J. (1991). Annotation: Growing up as a twin: Twin-singleton differences in psychological development. Journal of Child Psychology and Psychiatry, 32, 885-895.

Ryan, B. C., \& Vandenbergh, J. G. (2002). Intrauterine position effects. Neuroscience \& Biobehavioral Reviews, 26, 665-678.

Segal, N. L. (1999). Entwined lives: Twins and what they tell us about human behavior. New York: Dutton.
Skytthe, A., Kyvik, K. O., Holm, N. V., \& Christensen, K. (2011). The Danish Twin Registry. Scandinavian Journal of Public Health, 39, 75-78.

Slutske, W. S., Bascom, E. N., Meier, M. H., Medland, S. E., \& Martin, N.G. (2011). Sensation seeking in females from opposite- versus same-sex twin pairs: Hormone transfer or sibling imitation? Behavior Genetics, 41, 533542.

Sorensen, K., Juul, A., Christensen, K., Skytthe, A., Scheike, T., \& Kold Jensen, T. (2013). Birth size and age at menarche: A twin perspective. Human Reproduction, 28, 2865-2871.

Tapp, A. L., Maybery, M. T., \& Whitehouse, A. J. O. (2011). Evaluating the twin testosterone transfer hypothesis: A review of the empirical evidence. Hormones and Behavior, 60, 713-722.

Trzebiatowska, M., \& Bruce, S. (2012). Why are women more religious than men? Oxford: Oxford University Press.

vom Saal, F. S. (1989). Sexual differentiation in litter-bearing mammals: Influence of sex of adjacent fetuses in utero. Journal of Animal Science, 67, 1824-1840.

Winter, U., Hauri, D., Huber, S., Jenewein, J., Schnyder, U., \& Kraemer, B. (2009). The psychological outcome of religious coping with stressful life events in a Swiss sample of church attendees. Psychotherapy and Psychosomatics, 78, 240244.

Zuckerman, M., Silberman, J., \& Hall, J. A. (2013). The relation between intelligence and religiosity: A meta-analysis and some proposed explanations. Personality and Social Psychology, 17, 325-354.

Zuckerman, P. (2008). Society without God: What the least religious nations can tell us about contentment. New York: New York University Press. 